\title{
Denaturing HPLC for Identifying Bacteria
}

BioTechniques 33:386-391 (August 2002)

\author{
William Hurtle, David \\ Shoemaker ${ }^{1}$, Erik Henchal ${ }^{1}$, \\ and David Norwood ${ }^{1}$ \\ Clinical Research Management, \\ North Royalton, $\mathrm{OH}$, and ${ }^{1}$ United \\ States Army Medical Research \\ Institute of Infectious Diseases, \\ Fort Detrick, MD, USA
}

\section{INTRODUCTION}

Denaturing HPLC (DHPLC) is a rapid and sensitive method for detecting genetic mutations $(1,15)$. The technique consists of four parts: amplification by PCR, quantification, hybridization, and analysis of hybridized product. After PCR, heteroduplexes between wildtype and experimental products are formed during the hybridization step. Mismatches between the wild-type and mutant DNA sequences disrupt the structure of the heteroduplex, but DHPLC is capable of resolving these differences. Over the years, DHPLC has been employed in a wide range of applications, including nucleotide polymorphism analysis (3), gene mapping (13), analysis of genes (7), screening for mutations (8), analysis of primer extension products (6), and quantification of gene expression (5). Here we describe a new application for this technique - the identification of bacteria. Compared to current techniques of bacterial identification, DHPLC is quick, economical, and capable of screening large numbers of samples in a relatively short period of time.

In prokaryotes, the genes encoding rRNAs occur in tandem repeated arrays. Within the tandem array, each copy of the gene is identical or nearly identical. These genes are characterized by regions of high-sequence conservation and regions of sequence variability. Numerous reports have been published demonstrating the utility of analyzing these genes by PCR and other methods to distinguish different genera and species of bacteria $(2,9,12,14)$.

We amplified a 320-bp segment of the prokaryotic $16 \mathrm{~S}$ rRNA gene using conserved primer sequences that spanned a region of genetic variability. Thirty-nine species were tested to determine if DHPLC peak profile analysis could be used for identification. We also tested the ability of this method to specifically identify two organisms that have a high potential to be used as agents in bioterrorism, Yersina pestis and Bacillus anthracis. These two organisms were used as controls and tested against a panel of 65 bacterial strains.

\section{MATERIALS AND METHODS}

\section{Primer Design}

The primer set used in this study was designed by aligning the $16 \mathrm{~S}$ rRNA gene from Bacillus sp. (GenBank ${ }^{\circledR}$ accession no. L29507), Brucella melitensis (LZ6166), Enterococcus faecalis (Y18293), E. coli (X80724), Neisseria weaveri (L10738), Pseudomonas aeruginosa (AJ249451), Rickettsia rickettsii (L36217), Staphylococcus aureus (L37597), and Yersinia bercovieri (X75281). The primer set UNIV1U 5'ATTAGATACCCTGGTAGTCCACGC3' (sense) and UNIV1L 5'-TTGCGGG ACTTAACCCAAC-3' (antisense) was chosen from areas with a high degree of homology. The resultant 320-bp product spanned a region with a high degree of divergence. The primer set was analyzed with the software package Net Primer (Premier Biosoft, Palo Alto, CA, USA) for priming efficiency and synthesized on a model 394 DNA/RNA synthesizer (Applied Biosystems, Foster City, CA, USA). 


\section{DNA}

The DNA used in this study was from reference material obtained from recognized culture collections, com mercial vendors, clinics, or unique entries from previous USAMRIID collections. The DNA was extracted using either Bactozol ${ }^{\mathrm{TM}}$ Kits (Molecular Research Center, Cincinnati, OH, USA) or a BioRobot 9604B (Qiagen, Valencia, CA, USA), according to the manufacturer's recommendations.

\section{PCR}

Each organism was amplified in $100-\mu \mathrm{L}$ reactions containing $1 \mu \mathrm{M}$ each primer, $40 \mathrm{mM}$ each dNTP, $10 \mu \mathrm{L} \mathrm{10 \times}$ PCR Buffer II, 5 U AmpliTaq Gold ${ }^{\circledR}$ (Applied Biosystems), and $8 \mu \mathrm{L} 25 \mathrm{mM}$ $\mathrm{MgCl}_{2}$ in molecular biology-grade water. Two hundred picograms of template DNA were used in each reaction. The amplification was performed with a PTC-100 ${ }^{\mathrm{TM}}$ thermal cycler (MJ Research, Waltham, MA, USA). Cycling conditions were a 10-min preincubation at $95^{\circ} \mathrm{C}$ to activate the AmpliTaq Gold, followed by 30 cycles of $1 \mathrm{~min}$ at $95^{\circ} \mathrm{C}$, $1 \mathrm{~min}$ at $60^{\circ} \mathrm{C}, 1 \mathrm{~min}$ at $72^{\circ} \mathrm{C}$, and a 10 min final extension at $72^{\circ} \mathrm{C}$.

\section{Quantification}

PCR yields were quantitatively determined by reverse-phase HPLC using WAVE $^{\circledR}$ software and a DNA Fragment Analysis System ${ }^{\mathrm{TM}}$ (both from Transgenomic, Omaha, NE, USA) consisting of a L-7100 pump, L-7200 thermoelectronic-type constant temperature sample rack, L-7200 auto sampler, L-7300 column oven, L-7400 UV detector (all from Hitachi, San Jose, CA, USA), and a L-761 on-line degasser (ECR, Kawaguchi-City, Saitama, Japan). The mobile phase was composed of buffer A containing $0.1 \mathrm{M}$ triethylammonium acetate (Transgenomic), $\mathrm{pH} 7.0$, and $0.025 \%$ HPLC-grade acetonitrile (Fisher Scientific, Fair Lawn, NJ, USA) and buffer B containing $0.1 \mathrm{M}$ triethylam monium acetate, $\mathrm{pH} 7.0$, and $25 \%$ acetonitrile. The analytical gradient used for quantification was 0 min for $48 \% \mathrm{~A}$ and $52 \% \mathrm{~B} ; 0.5 \mathrm{~min}$ for $43 \% \mathrm{~A}$ and $57 \% \mathrm{~B} ; 5 \mathrm{~min}$ for $34 \% \mathrm{~A}$ and $66 \% \mathrm{~B}$; $5.1 \mathrm{~min}$ for $0 \% \mathrm{~A}$ and $100 \% \mathrm{~B} ; 5.7 \mathrm{~min}$ for $48 \% \mathrm{~A}$ and $52 \% \mathrm{~B}$; and $8.2 \mathrm{~min}$ for $48 \% \mathrm{~A}$ and $52 \% \mathrm{~B}$ at $0.9 \mathrm{~mL} / \mathrm{min}$. The columns used for analysis were $50 \times$ $4.4 \mathrm{~mm}$ (i.d.) DNASep ${ }^{\circledR}$ cartridges packed with nonporous polystrene-divinylbenzene copolymer particles $2.1 \pm$ $0.12 \mu \mathrm{m}$ in diameter. Fifteen microliters crude PCR product from each sample were injected onto the column.

\section{Heteroduplex Formation}

Hybridization reactions were performed using a PTC-100 thermal cycler in $200-\mu \mathrm{L}$ reactions containing $10 \mathrm{mM}$ EDTA (Invitrogen, Carlsbad, CA, USA) and equimolar amounts of B. anthracis Sterne strain PCR product and experimental PCR product in molecular biology-grade water (Eppendor ${ }^{\circledR}$, Westbury, NY, USA). The volume of the crude PCR product used in the hydridization reactions was standardized to $20000 \mathrm{U}$ as determined by the Transgenomic software. Hybridization conditions were a 4-min preincubation at $95^{\circ} \mathrm{C}$, followed by a cooling period from $-1.5^{\circ} \mathrm{C} / \mathrm{min}$ to $25^{\circ} \mathrm{C}$ over $45 \mathrm{~min}$.

\section{DHPLC Analysis}

To determine if this primer set would produce unique peak profiles, 39 species of bacteria were analyzed by DHPLC using $15-\mu \mathrm{L}$ injections of hybridized sample at $57^{\circ} \mathrm{C}, 58^{\circ} \mathrm{C}, 59^{\circ} \mathrm{C}$, $60^{\circ} \mathrm{C}, 61^{\circ} \mathrm{C}$, and $62^{\circ} \mathrm{C}$, with the analytical gradient of $0 \mathrm{~min}$ for $52 \% \mathrm{~A}$ and $48.0 \% \mathrm{~B} ; 0.5 \mathrm{~min}$ for $47 \% \mathrm{~A}$ and $53 \%$ $\mathrm{B} ; 5 \mathrm{~min}$ for $38 \% \mathrm{~A}$ and $62 \% \mathrm{~B} ; 5.1$ min for $0 \% \mathrm{~A}$ and $100 \% \mathrm{~B} ; 5.7 \mathrm{~min}$ for $52 \% \mathrm{~A}$ and $48 \% \mathrm{~B}$; and $8.2 \mathrm{~min}$ for $52 \% \mathrm{~A}$ and $48.0 \% \mathrm{~B}$ at $0.9 \mathrm{~mL} / \mathrm{min}$.

To determine the specificity of this method, a blind panel of 65 bacterial strains was analyzed at $57^{\circ} \mathrm{C}, 61^{\circ} \mathrm{C}$, $62^{\circ} \mathrm{C}$, and $63^{\circ} \mathrm{C}$ by using the analytical gradient, instrument, columns, and mobile phase previously described.

\section{Sequencing of PCR Products}

The PCR product was purified using a QIAquick ${ }^{\mathrm{TM}}$ spin column (Qiagen). Sequencing reactions were $20 \mu \mathrm{L}$ containing $2.5 \mu \mathrm{m}$ primer, $45 \mathrm{ng}$ PCR product, $1 \mu \mathrm{L}$ BigDye ${ }^{\mathrm{TM}}$ (Applied Biosystems), and molecular biologygrade water. Sequence cycling was per- formed on a PTC-100 thermal cycler. The sequence cycling conditions were $30 \mathrm{~s}$ preincubation at $85^{\circ} \mathrm{C}$, followed by 25 cycles of $10 \mathrm{~s}$ at $96^{\circ} \mathrm{C}, 5 \mathrm{~s}$ at $50^{\circ} \mathrm{C}, 4$ min at $60^{\circ} \mathrm{C}$, followed by a 10 -min final extension at $60^{\circ} \mathrm{C}$. The sequencing reactions were purified on Centri Sep columns (Princeton Seperations, Aldelphia, NJ, USA), and sequencing was performed on an ABI PRISM ${ }^{\mathrm{TM}} 377$ DNA sequencer, according to the manufacturer's recommendations.

\section{RESULTS AND DISCUSSION}

A primer set capable of amplifying a broad range of microorganisms was designed by aligning the $16 \mathrm{~S}$ RNA sequences of several bacteria from different genera. We found two regions of high conservation that spanned a region with relatively high sequence variability of about $320 \mathrm{bp}$. This primer set am plified all but two of the organisms used in this study, Bacteroides distasonis and Clostridium botulinum

From previous work in our laboratory with the vrrA region in $B$. anthracis, we noticed that distinct mutations produced unique DHPLC peak profiles (data not shown). Recently, reports have been published demonstrating that DHPLC can be useful in identifying mutations (4, $10,11)$. To see if it was possible to obtain unique peak profiles for each microorganism, we tested 39 species of bacteria from 24 genera (Table 1) over a temperature range of $57^{\circ} \mathrm{C}-62^{\circ} \mathrm{C}$ using $B$. anthracis Sterne as our heteroduplex driver.

We chose B. anthracis Sterne as our heteroduplex driver because of our familiarity with the organism from our previous work with the vrrA region. In addition, preliminary testing indicated that the product produced from the UNIV1U and UNIV1L primer set would hydridize with products from species highly divergent from $B$. anthracis Sterne. Given that B. anthracis Sterne hybridized to widely divergent species, we can speculate that any species of bacteria may be used as a heteroduplex driver using the UNIV1U and UNIV1L primers.

To ensure the reproducibility of peak profiles, before heteroduplex formation we quantified our PCR products with HPLC by measuring the area un- 


\section{Research Report}

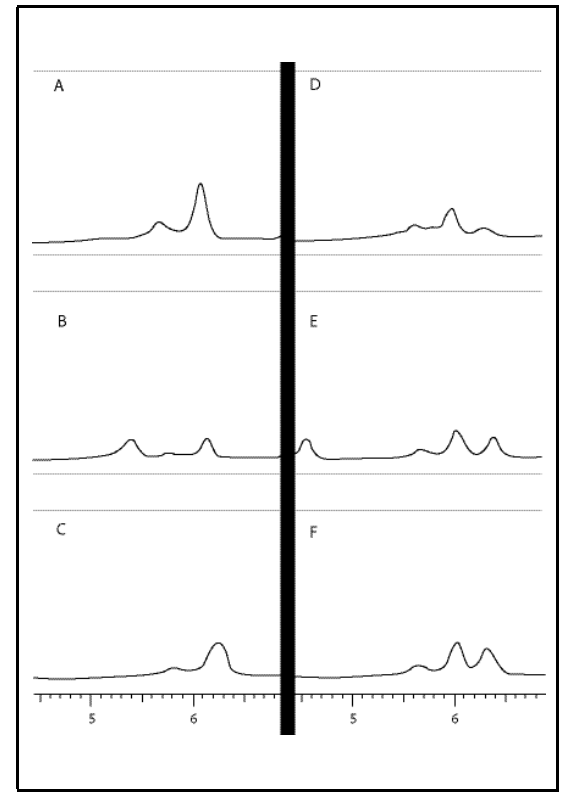

Figure 1. The unique peak profiles of (A) $B$. anthracis Sterne, (B) R. picketti, (C) S. enteritidis, (D) S. flexneri, (E) S. sonnei, and (F) $S$. pyogenes at $62^{\circ} \mathrm{C}$. The bacteria used in this study were distinguished from each other based on their unique profiles at a given temperature. $B$. anthracis Sterne is a homoduplex. R. picketti, S. enteritidis, S. flexneri, S. sonnei, and S. pyogenes are homoduplexes, with $B$. anthracis Sterne as the heteroduplex driver. obtained when analyzing organisms of great sequence divergence, we did three injections of each of the 39 organisms on four different days. One organism tested, E. coli, gave us inconsistent results at $61^{\circ} \mathrm{C}$. Interestingly, this was the only organism that presented this problem and only at this one temperature.

We also observed differences in peak profiles from column to column. While each column gave us highly reproducible results, there were differences in peak profiles between columns (Figure 3). In addition, on any given column, the relative retention time between peaks increased as the number of injections on the column increased (Figure 4, A and B). However, even after injecting 4000 samples on a column, we were still able to get reproducible results on a single run of four organisms at six different temperatures with three injections of each organism at each temperature (Figure 4, C and D).

To evaluate DHPLC as a method of identifying bacteria, we tested two control organisms, $Y$. pestis and $B$. anthracis, against a blinded panel of 65 organisms (Table 2). Of the $10 \mathrm{Y}$. pestis

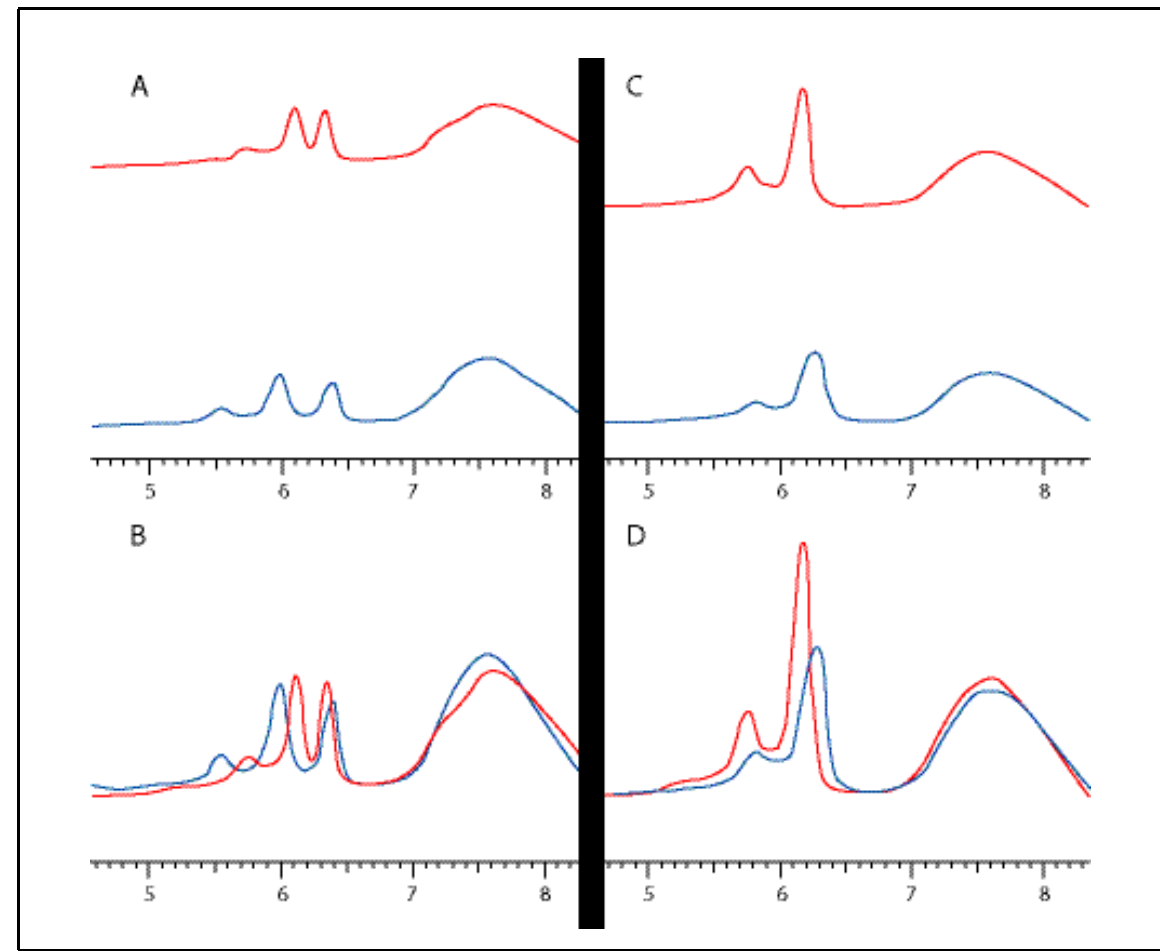

Figure 2. Peak profiles of (A) Y. enterocolitica and $S$. sonnei at $62^{\circ}$ C. (B) Overlay of $Y$. enterocolitica and $S$. sonnei at $62^{\circ} \mathrm{C}$. (C) B. anthracis Sterne and S. enteritidis at $62^{\circ} \mathrm{C}$. (D) Overlay of B. anthracis Sterne and $S$. enteritidis at $62^{\circ} \mathrm{C}$. Some organisms had similar peak profiles. These organisms were distinguished from each other by overlaying chromatograms.

samples on the panel, 10 were identified correctly. Of the $14 \mathrm{~B}$. anthracis strains, 12 strains were identified correctly. There were no false positives. Of the two false negatives, one was the result of a quantification miscalculation. The other was a $B$. anthracis strain with a unique peak profile. Given the high degree of specificity, these results (Table 2) indicate that DHPLC can be used to screen a large number of sam ples for organisms of interest.

With the capability of DHPLC to detect variations in DNA sequences, its high throughput, and the utility of rRNA genes in identifying bacteria, it may be possible to refine further this method of identifying microorganisms, allowing for the screening of a large number of samples relatively quickly. It may be possible to analyze additional regions of an rRNA gene of variability for increased identification at the species level. Furthermore, specific regions of genetic variability within species could be exploited for strain typing. DHPLC appears to be a promising technique for identifying and genetically characterizing bacteria at the molecular level without sequencing DNA.

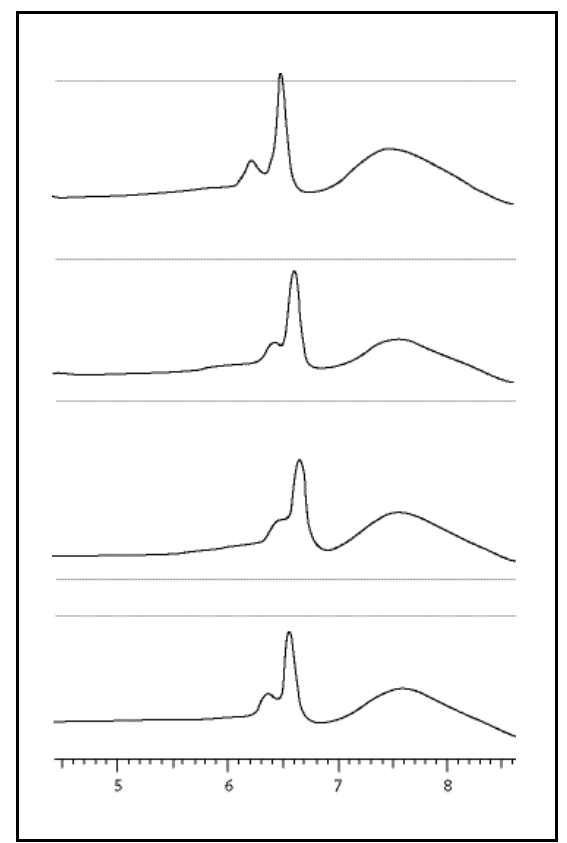

Figure 3. Various columns with B. anthracis Sterne at $61^{\circ} \mathbf{C}$. Each column tested had variations in retention times, relative retention times, number of peaks, and peak shape. 


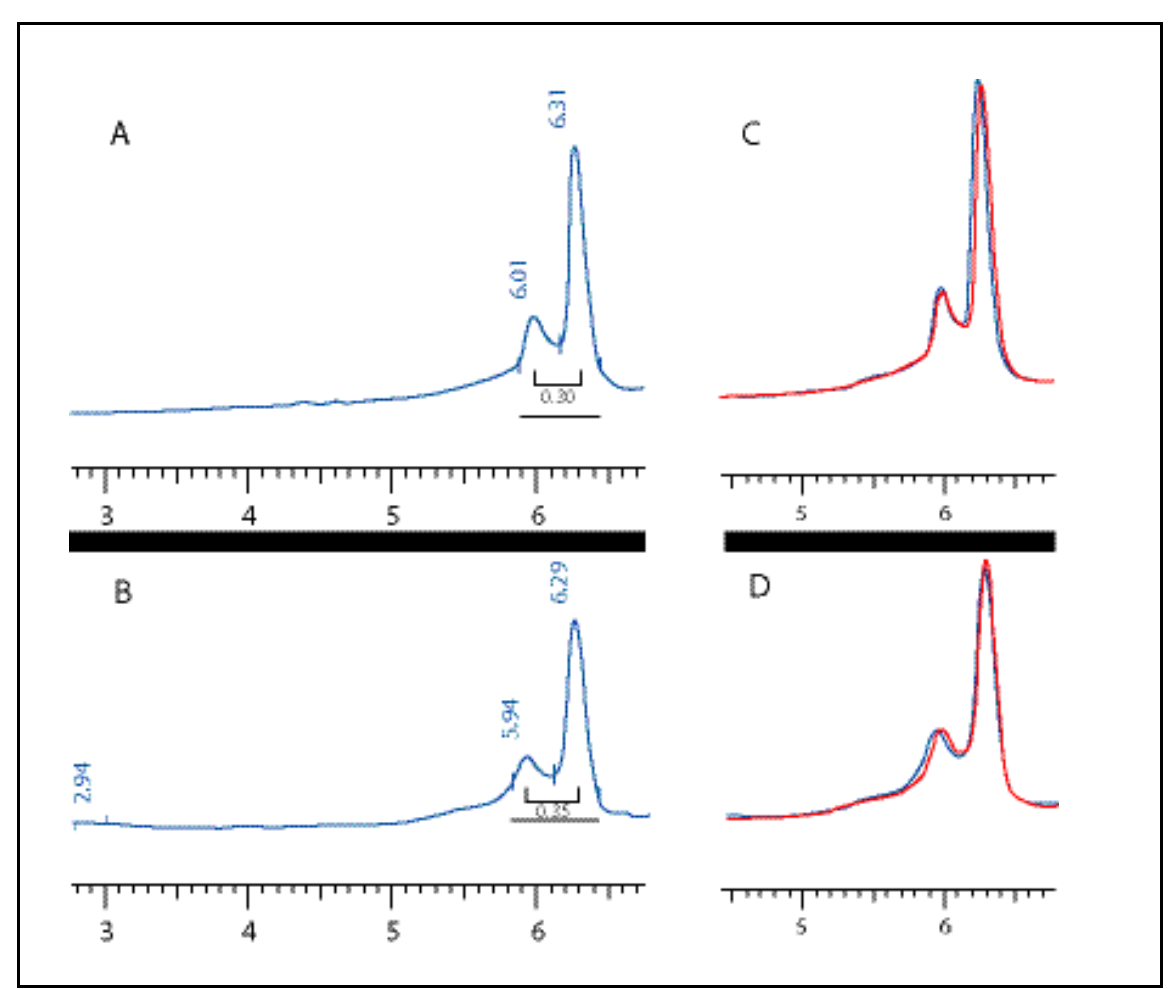

Figure 4. The increase in relative retention time between the two peaks of $B$. anthracis Sterne at $62^{\circ} \mathrm{C}$ after 370 and 3450 runs. The relative retention time between the two peaks of $B$. anthracis Sterne at (A) 370 runs was $0.30 \mathrm{~min}$, and at (B) 3450 runs it was $0.35 \mathrm{~min}$. Overlays of B. anthracis Sterne at (C) 370-373 runs and (D) 3450-3453 runs. Although the relative retention time between the two peaks increased, peak profiles within a given run are highly reproducible.

\section{ACKNOWLEDGMENTS}

The authors thank Karina Hagar, Steve Kerby, and Heather Sines for their help in sequencing DNA and Dr. Pat Worsham for supplying strains of $Y$. pestis used in this study. This study was conducted as part of a thesis research project for Hood College. The work was funded by an Independent Laboratory Investigator Research grant and a Genetically Engineered Microbe grant from the United States Army Medical Research of Infectious Diseases.

\section{REFERENCES}

1.Arnold, N., E. Gross, U. Schwarz-Boeger, J. Pfisterer, W. Jonat, and M. Kiechle. 1999. A highly sensitive, fast, and economical technique for mutation analysis in hereditary breast and ovarian cancers. Hum. Mutat. 14:333-339.

2.Bennasar, A., G. De Luna, B. Cabrer, and J. Lalucat. 2000. Rapid identification of Salmonella typhimurium $S$. enteritidis, and $S$. virchow isolates by polymerase chain reaction based fingerprinting methods. Int. Microbiol. 3:31-38.

3.Cargill, M., D. Altshuler, J. Ireland, P. Sklar,
K. Ardlie, N. Patil, N. Shaw, C.R. Lane, et. al. 1999. Characterization of single nucleotide polymorphisms in coding regions of human genes. Nat. Genet. 22:231-238.

4.Gross, E., N. Arnold, K. Pfeifer, K. Brandick, and M. Kiechle. 2000. Identification of specific BRAC1 and BRAC2 variants by DHPLC. Hum. Mutat. 16:345-353.

5.Hayward-Lester, A., P.J. Oefner, and P.A. Doris. 1996. Rapid quantification of gene expression by competitive RT-PCR and ion-pair reversed phase HPLC. BioTechniques 20:250257.

6.Hoogendoorn, B., M.J. Owen, P.J. Oefner, N. Williams, J. Austin, and M. O'Donovan. 1999. Genotyping single nucleotide polymorphisms by primer extension and high performance liquid chromatography. Hum. Genet. 104:89-93.

7.Liu, W.O., P.J. Ofner, C. Qain, R.S. Odom, and U. Francke. 1998. Denaturing HPLC identified novel FBN1 mutations, polymorphisms, and sequence variants in Marfan syndrome and related connective tissue disorders. Genet. Test. 1:237-242.

8.McCallum, C.M., L. Comai, E.A. Greene, and S. HeniKoff. 2000. Targeted screening for induced mutations. Nat. Biotechnol. 18:455457.

9.Neubauer, H., H. Meyer, J. Prior, S. Aleksic, A. Hensel, and W. Splettstosser. 2000. A combination of different polymerase chain reaction (PCR) assays for the presumptive identification of Yersinia pestis. J. Vet. Med. B. In- fect. Dis. Vet. Public Health 47:573-580.

10.Nickerson, M.L., G. Weirich, B. Zbar, and L.S. Schmidt. 2000. Signature-based analysis of MET proto-oncogene mutations using DH PLC. Hum. Mutat. 16:68-78.

11.O'Donovan, M.C., P.J. Oefner, S.C. Roberts, J. Austin, B. Hoogendoorn, C. Guy, G. Speight, M. Upadhyaya, et al. 1998. Blind analysis of denaturing high-performance liquid chromatography as a tool for mutation detection. Genomics 52:44-49.

12.Raghava, G.P., R.J. Solanki, V. Soni, and P. Agrawal. 2000. Fingerprinting method for phylogenic classification and identification of microorganisms based on variation in $16 \mathrm{~S}$ rRNA gene sequences. BioTechniques 29:108 116.

13.Schriml, L.M., R.J. Peterson, B. Gerrard, and M. Dean. 2000. Use of denaturing HPLC to map human and murine genes and to validate single nucleotide polymorphisms. BioTechniques 28:740-745.

14.Stender, H., A.J. Broomer, K. Oliveira, H. Perry-O'Keefe, J.J. Hylding-Nielsen, A. Sage, and J. Coull. 2001. Rapid detection, identification, and enumeration of $E$. coli cells in municipal water by chemiluminescent in situ hybridization. Appl. Environ. Microbiol. 67:142-147.

15.Xiao, W. and P.J. Oefner. 2001. Denaturing high-performance liquid chromatography: a review. Hum. Mutat. 17:439-474.

Received 4 September 2001; accepted 13 March 2002.

Address correspondence to:

Dr. David Norwood

United States Army Medical Research Institute

of Infectious Diseases

Diagnostic Systems Division

1425 Porter Street

Fort Detrick, MD 21702, USA

e-mail:david.norwood@det.amedd.army.mil

For reprints of this or any other article, contact Reprints@BioTechniques.com 